\title{
Design and Development of Low Cost and Light Weight Microwave filters by using Metalized ABS Plastic as a Substitute of High Cost Substrate and Metals
}

\author{
Jagdish Shivhare \\ Department of Electrical, Electronics and \\ Communication Engineering \\ ITM University, Gurgaon, Sector-23A, India
}

\author{
S. B. Jain \\ Department of Electronics and Communication \\ Indira Gandhi Institute of Technology, Indraprashth \\ University, Delhi, India
}

\begin{abstract}
The main objective to introduce the ABS (Acryonitrile Butadyne Styrene) plastic substrate in place of RT- Duroid substrate for microstrip filters is to reduce the cost. The cost of plated ABS plastic substrate is substantially less (Rs. 4/sq.inch) compared to the cost of RT-Duroid (US\$ 02/-/sq.inch). Two microstrip (hairpin line) band pass filters at 1537.5 MHZ and 1575.42 MHz have been developed and tested. The performance of filters have been verified over temperature range, $-10 \mathrm{deg}$. $\mathrm{C}$ to $60 \mathrm{deg}$. C.The ABS plastic blocks have been used in place of metal blocks of brass, copper and Commercial Aluminium to fabricate three dimensional microwave cavity filters for communication systems. The specific gravity of ABS plastic is $1.03 \mathrm{gms} /$ cubic $\mathrm{cm}$ compare to $2.7,6.3$ and $9.6 \mathrm{gms} / \mathrm{cubic} \mathrm{cm}$ of $\mathrm{Com}$. $\mathrm{Al}$, Copper and Brass respectively. Hence the weight of metallized ABS cavity filters will be 1/3rd , 1/6th and 1/9th of the com. Al, copper and brass cavity filters.
\end{abstract}

\section{General Terms}

Acryonitrile butadiene styrene plastic, poly tetra flouroehtelene, RT-duroid, thermal conductivity, surface resistivity, heat distortion temperature, coating, plating.

\section{Keywords}

Microstrip, substrate, hairpin line filter, dielectric constant, insertion loss, dissipation factor, quality factor, bandwidth

\section{INTRODUCTION}

With the development of the electronic industry in India, there is continuous need for new materials having better performance properties with stringent size and weight limitation. Such needs can be tailor made by plastic materials, which have very high rate of environmentally safe processablility and production process, maintaining the accuracy and level of functional properties. As new plating processes groom, metalized plastics play a bigger role as replacement of conventional materials on cost, weight and performance basis. Currently plated thermoplastic ABS is widely used in automotive and decorative uses but is untouched for passive microwave component applications in communication.

\section{CHOICE OF MATERIAL}

At microwave frequencies the current density is maximum near the surface and it falls off exponentially with depth. Thus as long as there is a thin layer of silver, copper or any other highly conductive material on surface, the body can be of wood, plastic or anything else; without affecting the microwave propagation. In addition to size and weight the other factors determining the type of body material are machining tolerances, water absorption, ability to handle power, efficiency, problems in matching, shielding, and reliability[1]

Acrylonitrile Buadiene Styrene (ABS) plastic has excellent toughness, rigidity and gloss[2][3]. They are cheaper than engineering plastics like nylons, polyacetals and polycarbonates. The important physical and electrical properiates like tensile modulus, tensile strength, surface hardness, porosity, coefficient of thermal expension, thermal conductivity, heat distortion temperature, dielectric strength, dissipation factor, surface resistivity, etc. were found to be favorable for such applications. Moulding from ABS exhibit better and uniform impact strength in all the directions. Another important feature of ABS is that it is the only plastic which can be commercially electroplated. It is found that electroplated ABS parts show improvement in properties like surface hardness, tensile and flexural strength, heat resistance, chemical resistance, weather resistance etc. The electrical properties of ABS plastics are unaffected by temperature and humidity. Dielectric strength, power factor, and dielectric constant are reasonably good to allow it to be used in electronic or electrical applications like coil formers, connectors, wave guides etc[3].Thus for our study, ABS (platable) plastic material was selected for the design, development and fabrication of substrate type (instead of RTDuroid) and cavity type (instead of metal) band pass filters in microwave frequency range for communication systems[4].

\section{COATING/PLATING PROCEDURE}

The copper thickness was built by electroplating. Silver plating is done after deposition of copper on plastic. The deposits were subjected to environmental tests such as humidity and corrosion resistance, thermal cycling, thermo vacuum, baking, hot and cold storage etc. tape test was used to check the adhesion of the coating after each test. Mechanical properties of the coatings were evaluated by micro hardness test, surface roughness and peel strength. To verify the assumption of replacement of very costly substrates and metals with plated ABS plastic, some planar structured(hairpin line) and cavity type band pass filters (coaxial, helical and comb line) having different centre frequencies and bandwidths were designed and fabricated. The standard design tools and techniques were used for all types of cavity band pass filters but for hairpin line filters necessary design corrections were applied [5][14][15]. 
ABS with $10 \%$ butadiene is more suitable for electroplating than ABS with 16 to $27 \%$ butadiene. Several trials were conducted for electroplating on ABS plastic. The articles were immersed in the mixture of chromic acid and sulphuric acid to improve mechanical adhesion. Poor etching leads to skip plating or poor adhesion of the plating and possible blistering. Thus etched articles are not to be treated with sensitizer and activators stannous chloride and palladium chloride solution are used for this purpose. The deposited palladium nuclei on the plastic surface, initiates electroless plating of copper or nickel or gold or other metals. We have carried out electroless copper deposition for our work. Finally deposited with electroplated copper or silver to get highly conductive surface.

Table 1. Properties comparison (as per data sheet and catalogues)

\begin{tabular}{|c|c|c|c|}
\hline $\begin{array}{l}\text { Sr. } \\
\text { No. }\end{array}$ & Property & RT - Duroid \# 5880 & ABS - Plastic \# AP78EP \\
\hline 01. & $\begin{array}{l}\text { Dielectric Constant } \\
\text { Er ( relative ) }\end{array}$ & $\begin{array}{l}\left(2.22-^{+} 0.02\right) \\
\text { upto } 10 \mathrm{GHz} \\
(\text { Eeff }=1.89 \text { for } 50 \text { line })\end{array}$ & $\begin{array}{l}\mathrm{Er}=(2.8-3.8) \text { at } 1 \mathrm{MHz} \\
\text { Eeff }=(1.89 \text { to } 2.12) \text { upto } 10 \mathrm{GHz} \\
\text { measured on HP } 8510 \text { Table- } 1\end{array}$ \\
\hline 02. & Dissipations factor ( ten ) & $\begin{array}{l}(0.0009 \text { to } 0.0010) \\
\text { UP TO } 10 \mathrm{GHz}\end{array}$ & $\begin{array}{l}0.0024 \text { at } 9.2 \mathrm{GHz} \\
\text { (measured) }\end{array}$ \\
\hline 03. & Specific gravity & $2.20 \mathrm{gms} / \mathrm{gm}^{3}$ & $1.05 \mathrm{gms} / \mathrm{cm}^{3}$ \\
\hline 04. & $\begin{array}{l}\text { Heat distortion } \\
\text { temperature }\end{array}$ & $>260^{\circ} \mathrm{C}$ & $84^{0} \mathrm{C}$ \\
\hline 05. & Power handling capability & $120 \mathrm{~W}$ & $72 \mathrm{~W}$ \\
\hline 06. & $\begin{array}{l}\text { Thermal Expansion } \\
\text { (Linear) }\end{array}$ & $48 \times 10^{-6} \mathrm{~mm} / \mathrm{mm} /{ }^{0} \mathrm{C}$ & $70 \times 10^{-6} \mathrm{~mm} / \mathrm{mm} /{ }^{0} \mathrm{C}$ \\
\hline 07. & Tensile strength & $450 \mathrm{Kg} / \mathrm{gm}^{2}$ & $430 \mathrm{Kg} / \mathrm{gm}^{2}$ \\
\hline 08. & Volume resistivity & $2 \times 10^{13}$ to $2 \times 10^{14} \mathrm{ohm}-\mathrm{cm}$ & $10^{13}$ to $10^{16} \mathrm{ohm} / \mathrm{cm}$ \\
\hline 09. & Elongation at Break & $17.6 \%$ & $25 \%$ \\
\hline 10. & Hardness R-scale & $\mathrm{R}-88$ & $R-110$ \\
\hline 11. & Deformation under Load & $(0.6-1.0) \%$ & $\left(\begin{array}{lll}0.4 & 0.6\end{array}\right) \%$ \\
\hline 12. & Tensile modules & $30 \times 10^{3} \mathrm{Kg} / \mathrm{gm}^{2}$ & $23 \times 10^{3} \mathrm{Kg} / \mathrm{gm}^{2}$ \\
\hline
\end{tabular}

\section{PERFORMANCE EVAluation}

The transmission characteristics of metalized ABS plastic filters in the form of substarte and cavity were tested to compare with RT-Duroid and commercial Aluminum filters by using the network analyzer. The electrical parameters of metalized ABS filters; like centre frequency, insertion loss at the centre frequency, $3 \mathrm{~dB}$ bandwidth, stop band attenuation were measured and compared with that made from RT-Duroid and Aluminum alloy in the temperature range from $-20 \operatorname{deg} \mathrm{C}$ to -60deg $\mathrm{C}$, as shown in the comparison tables. Thus this new plastic material is getting use in making different types of band pass filters for ground and space application [6][7]

Though, the dielectric constant and dissipation factor above 1 $\mathrm{MHz}$ are not given in the literature, we have measured effective dielectric constant (Ceff) up to $10 \mathrm{GHz}$ and verified practically by the performance of two hairpin line band pass filters at 1537.5 and $1575.42 \mathrm{MHz}$. The insertion loss is more due to higher dissipation factor. So if the insertion loss is not very critical, the very low cost microstrip hairpin line filters Duroid, supplied by Rogers Corp. USA. We have measured Ceff for ABS plastic and RT-Duroid, having electrical can be developed by using plated plastic substrate in place of RT-Duroid ( $\# 5880, \epsilon r=2.22)$. The measurement method of Ceff also has been verified by cross checking the value of Ceff for RT-Duroid (\#5880), for 50 ohms line up to $10 \mathrm{GHZ}$ (Table 1) on network analyzer HP-8510[8][10][12]

\section{DESIGN PROCEDURE}

The design procedure available for RT-Duroid \#5880 has been applied to calculate the dimensions of resonators for hairpin line filters. The existing design tables and graphs are sufficient to carry out the design calculations[9][11][16][18]

\section{EXPERIMENTAL RESULTS}

Two hairpin line microstrip band pass filters have been optimized on Network Analyzers HP8754 A and HP8510. The resonator lengths, practically found at $1537.5 \mathrm{MHz}$ and $1575.42 \mathrm{MHz}$ have been verified the correctness of measured Ceff of ABS plastic substrate[5]. The correctness of measurement method is also verified with the help of value of Eeff, measured and available in the data sheet of \# 5880, RTlengths of 150 and $50 \mathrm{~mm}$ of $50 \mathrm{ohms}$ microstrip line of each substrate material (table-1).In our experiments we used the 
microstrip filters fabricated on ABS plastic substrate by using positive/negative of RT-Duroid based filters. The centers of response were achieved at lower frequencies than that of RTDuroid. The filters were optimized by trimming-out the resonator lengths. The band widths with respect to center frequencies were not similar to RT-Duroid based filters in both cases.[13][15]

So, if the insertion loss and bandwidth are not critical, low cost microstrip filters can be developed by using ABS-plastic substrate as an alternative to RT-Duroid substrate [9][10].

Table 2. Measurement of Effective Dilectric Constant(Geff ) of ABS on Network Analyzer

\begin{tabular}{|c|c|c|c|c|c|c|c|c|}
\hline \multirow{3}{*}{$\begin{array}{l}\text { Frequency of } \\
\text { measurement in } \\
\mathrm{MHz}\end{array}$} & \multicolumn{4}{|c|}{ RT.DUROID \#5880 } & \multicolumn{4}{|c|}{ ABS-PLASTIC \# AP78 EP } \\
\hline & \multicolumn{2}{|c|}{$\begin{array}{l}\text { Measured Electrical length in } \\
(\mathrm{mm}) \text { for }\end{array}$} & \multirow[t]{2}{*}{$\epsilon$ eff } & \multirow[t]{2}{*}{$\epsilon$ eff } & \multicolumn{2}{|c|}{$\begin{array}{l}\text { Measured Electrical length in } \\
(\mathrm{mm}) \text { for }\end{array}$} & \multirow[t]{2}{*}{$\epsilon$ eff } & \multirow[t]{2}{*}{$\epsilon$ eff } \\
\hline & $\begin{array}{l}150 \mathrm{~mm} \text { physical } \\
\text { length of } 50 \\
\text { Ohm line }\end{array}$ & $\begin{array}{l}50 \mathrm{~mm} \\
\text { physical } \\
\text { length of } 50 \\
\text { Ohm line }\end{array}$ & & & $\begin{array}{l}150 \mathrm{~mm} \\
\text { physical length } \\
\text { of } 50 \mathrm{Ohm} \text { line }\end{array}$ & $\begin{array}{l}50 \mathrm{~mm} \\
\text { physical } \\
\text { length of } 50 \\
\text { Ohm line }\end{array}$ & & \\
\hline 45.0 & 230.76 & 96.26 & 1.345 & 1.81 & 231.22 & 93.82 & 1.374 & 1.89 \\
\hline 650.0 & 232.18 & 96.18 & 1.360 & 1.85 & 233.15 & 95.35 & 1.378 & 1.90 \\
\hline 1500.0 & 234.49 & 97.79 & 1.367 & 1.87 & 234.61 & 95.71 & 1.389 & 1.93 \\
\hline 2500.0 & 235.82 & 97.62 & 1.382 & 1.91 & 235.70 & 95.40 & 1.403 & 1.97 \\
\hline 4500.0 & 236.75 & 97.15 & 1.396 & 1.95 & 237.14 & 96.14 & 1.410 & 1.99 \\
\hline 7000.0 & 242.11 & 97.91 & 1.442 & 2.08 & 250.32 & 108.22 & 1.421 & 2.0 \\
\hline 10000.0 & 251.43 & 106.53 & 1.449 & 2.10 & 263.07 & 117.47 & 1.456 & 2.1 \\
\hline \multicolumn{5}{|c|}{$\begin{array}{l}\text { From DATA sheet of REGOERS CORP. } \\
E r=2.22 \pm 0.02, \text { up to } 10 \mathrm{GHz} . \epsilon \text { eff }=1.89 \text { for } 50 \mathrm{ohm} \text { line. Dissipation } \\
\text { factor: } 0.0009 . \text { Measured } € \text { eff is approximately equal to actual } € \text { eff }(1.89) \text {. } \\
\text { Which verifies correctness or our test method of measurement. (Table-2) }\end{array}$} & \multicolumn{4}{|c|}{$\begin{array}{l}\text { From DATA sheet by ABSTRON Er }=(2.8-3.3) \text { at } \\
1 \mathrm{MHz} . \epsilon \text { eff (measure) }=1.89-2.12 \text { for } 50 \mathrm{ohm} \text { line } \\
\text { from } 45 \mathrm{MHz} \text { to } 10 \mathrm{GHz} \text {. Dissipation factor: } 0.0024 \\
\text { at } 9.0 \mathrm{GHz} \text {. Measured by wave guide method. } \\
19 \times 19 \times 3 \mathrm{~mm}^{3} \text { sheet of ABS plastic. }\end{array}$} \\
\hline
\end{tabular}

Table 3. Verification of correctness of our test method

\begin{tabular}{|c|c|c|}
\hline S.No. & $\begin{array}{l}\text { For RT-DUROID \# } 5880 \mathrm{~T} \\
\text { ROGERS CORP. USA }\end{array}$ & $\begin{array}{l}\text { For ABS-PLASTIC \# AP78EP } \\
\text { ABSTRON INDIA }\end{array}$ \\
\hline 01. & Thickness of substrate: $1-6 \mathrm{~mm}$ & Chosen thickness for filters: 1-6mm \\
\hline 02. & $\begin{array}{l}\text { As per DATA sheet: } \\
\epsilon \text { eff }=1.89 \text { for } 50 \mathrm{ohm} \text { line upto } 10 \mathrm{GHz}\end{array}$ & Measured $\epsilon$ eff $=1.89$ to 2.12 from $45 \mathrm{MHz}-10 \mathrm{GHz}$ \\
\hline 03. & $\begin{array}{l}\text { Length of resonator }\left(\frac{\lambda}{4}\right) \text { at } 1537.5 \mathrm{MHz} \& 1575.42 \mathrm{MHz} \\
\frac{\lambda}{4}=\frac{3 \times 10^{11}}{4 \times 1537.5 \times 10^{6} \sqrt{1.89}} \\
=35.628 \text { at } 1537.5 \mathrm{MHz} \\
\frac{\lambda}{4}=34.483 \text { at } 1575.42 \mathrm{MHz}\end{array}$ & 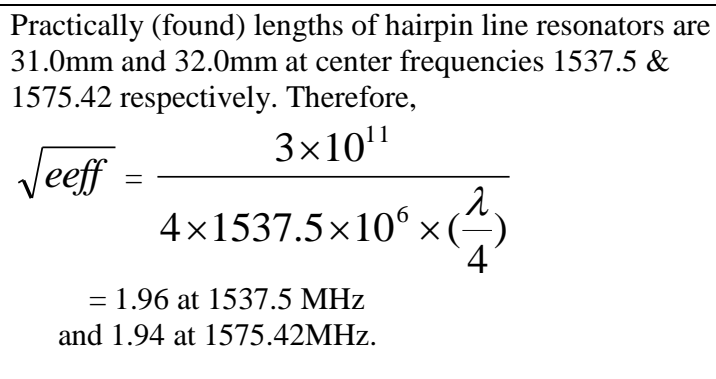 \\
\hline 04. & $\begin{array}{l}\text { By our test method, } \epsilon \text { eff }=1.87 \text { at } 1500 \mathrm{MHz} \text { and varies form } \\
1.89 \text { to } 2.12 \text { for } 45 \mathrm{MHz} \text { to } 10 \mathrm{GHz} \text {. Thus the measured } \\
\text { values of } \epsilon \text { eff are very close to the actual } \epsilon \text { eff ( } 1.89 \text { for } 50 \\
\text { ohm line), which verifies the correctness of our test method. }\end{array}$ & $\begin{array}{l}\text { By the same test method, } \epsilon \text { eff }=1.93 \text { (Table- } 1 \text { ) for } \\
\text { which is very close to the values found practically, } \epsilon \\
\text { eff }=1.94 \& 1.96 \text { at } 1537.5 \mathrm{MHz} \& 1575.42 \mathrm{MHz} \text {. This } \\
\text { also provides the proof of the correctness of our method } \\
\text { adopted for measurements of } \epsilon \text { eff. }\end{array}$ \\
\hline
\end{tabular}


Table 4. Achieved Results at various temperatures

\begin{tabular}{|c|c|c|c|c|c|c|c|c|c|c|c|}
\hline \multicolumn{12}{|c|}{ Test temperatures } \\
\hline \multirow{2}{*}{ Parameter } & \multirow{2}{*}{ Unit } & \multicolumn{2}{|c|}{$\begin{array}{c}\text { Room } \\
\text { temperature }\end{array}$} & \multicolumn{2}{|c|}{$-10^{0} \mathrm{C}$} & \multicolumn{2}{|c|}{$-20^{\circ} \mathrm{C}$} & \multicolumn{2}{|c|}{$+50^{\circ} \mathrm{C}$} & \multicolumn{2}{|c|}{$+65^{\circ} \mathrm{C}$} \\
\hline & & $\begin{array}{l}\text { Com } \\
\text { A1 }\end{array}$ & $\begin{array}{l}\text { ABS } \\
\text { plastic }\end{array}$ & $\begin{array}{l}\text { ComA } \\
1\end{array}$ & $\begin{array}{l}\text { ABS } \\
\text { plastic }\end{array}$ & ComA1 & $\begin{array}{l}\text { ABS } \\
\text { plastic }\end{array}$ & ComA1 & $\begin{array}{l}\text { ABS } \\
\text { plastic }\end{array}$ & $\begin{array}{l}\text { Com. } \\
\text { A1 }\end{array}$ & $\begin{array}{l}\text { ABS } \\
\text { plastic }\end{array}$ \\
\hline $\begin{array}{l}\text { Center } \\
\text { Freq. }\end{array}$ & $\mathrm{MHz}$ & 1636 & 1636 & $\begin{array}{c}1636 . \\
5\end{array}$ & 1636.3 & 1639 & 1638 & 1635.6 & 1635.7 & 1632 & 1634 \\
\hline $\begin{array}{c}0.1 d B \\
\text { BW }\end{array}$ & $\mathrm{MHz}$ & \pm 10 & \pm 10 & \pm 9.5 & \pm 9.9 & \pm 9.2 & \pm 9.7 & \pm 9.6 & \pm 9.9 & \pm 9.2 & \pm 9.6 \\
\hline $\begin{array}{c}\text { 3.0dB } \\
\text { BW }\end{array}$ & $\mathrm{MHz}$ & \pm 20 & \pm 20 & $\frac{ \pm}{19.5}$ & \pm 19.6 & \pm 19.1 & $\underset{ \pm}{ \pm}$ & \pm 20.0 & \pm 20.0 & \pm 19.3 & \pm 19.6 \\
\hline
\end{tabular}

Table 5. Design and development of various types of metal cavity bandpass filters

\begin{tabular}{|c|c|c|c|c|c|c|c|c|}
\hline $\begin{array}{l}\text { Type of } \\
\text { filter }\end{array}$ & $\begin{array}{l}\text { Freq. } \\
\text { Band } \\
\text { MHz }\end{array}$ & $\begin{array}{l}\text { Center } \\
\text { Freq. } \\
\text { MHz }\end{array}$ & $\begin{array}{l}\text { Band } \\
\text { width } \\
\text { MHz }\end{array}$ & $\begin{array}{c}\text { Insertion } \\
\text { loss } \\
\text { dB }\end{array}$ & $\begin{array}{c}\text { I/O } \\
\text { return } \\
\text { loss } \\
\text { dB }\end{array}$ & $\begin{array}{c}\text { Stop band } \\
\text { attenuation } \\
\text { dBc }\end{array}$ & $\begin{array}{c}\text { Size } \\
\text { (LxBxH) } \\
\text { MMxMMxM } \\
\text { M }\end{array}$ & $\begin{array}{l}\text { Weight } \\
\text { grams }\end{array}$ \\
\hline \multicolumn{9}{|l|}{ VHF/UHF } \\
\hline Helical & $52-55$ & 53.5 & \pm 1.5 & 1.0 & 16 & 30dBc @60MHz & $200 \times 50 \times 72$ & 80 \\
\hline Helical & $85-88$ & 86.5 & \pm 1.5 & 1.0 & 16 & 30dBc @80MHz & $200 \times 50 \times 72$ & 80 \\
\hline Helical & $320-328$ & 324.0 & \pm 4.0 & 6.0 & 15 & $>30 \mathrm{dBc} @ \pm 8 \mathrm{MHz}$ & $105 \times 38 \times 25$ & 41 \\
\hline Helical & $591-609$ & 600.0 & \pm 9.0 & 2.2 & 20 & $>30 \mathrm{dBc} @ \pm 18 \mathrm{MHz}$ & $100 \times 23 \times 33$ & 28 \\
\hline Combline & $1050-1350$ & 1200.0 & \pm 150 & 1.5 & 15 & $>30 \mathrm{dBc} @ \pm 300 \mathrm{MHz}$ & $155 \times 45 \times 30$ & 55 \\
\hline \multicolumn{9}{|l|}{$L-B A N D$} \\
\hline Co-axial & $1530-1545$ & 1537.5 & \pm 7.5 & 0.4 & 20 & $>30 \mathrm{dBc} @ \pm 90 \mathrm{MHz}$ & $130 \times 44 \times 37$ & 90 \\
\hline Co-axial & $1626-1646$ & 1636.0 & \pm 10 & 0.4 & 20 & $>30 \mathrm{dBc} @ \pm 90 \mathrm{MHz}$ & $152 \times 52 \times 41$ & 130 \\
\hline \multicolumn{9}{|l|}{ S-BAND } \\
\hline Combline & $2500-2690$ & 2595.0 & \pm 85 & 1.5 & 16 & $\begin{array}{l}>30 \mathrm{dBc} @ \pm \\
2000 \mathrm{MHz}\end{array}$ & $120 \times 25 \times 20$ & 110 \\
\hline \multicolumn{9}{|l|}{ C-BAND } \\
\hline Combline & $4170-4200$ & 4190.0 & \pm 20 & 1.5 & 15 & $>30 \mathrm{dBc} @ \pm 40 \mathrm{MHz}$ & $107 \times 21 \times 18$ & 30 \\
\hline Combline & $4570-4610$ & 4590.0 & \pm 20 & 1.5 & 15 & $>30 \mathrm{dBc} @ \pm 40 \mathrm{MHz}$ & $126 \times 23 \times 17$ & 40 \\
\hline Combline & 5850-5930 & 5890.0 & \pm 40 & 2.0 & 16 & $>30 \mathrm{dBc} @ \pm 80 \mathrm{MHz}$ & $95 \times 18 \times 12$ & 50 \\
\hline \multicolumn{9}{|l|}{$\begin{array}{l}\text { Ext. C- } \\
\text { BAND }\end{array}$} \\
\hline Combline & $6725-7025$ & 6835.0 & \pm 150 & 2.0 & 15 & $>30 \mathrm{dBc} @ \pm 500 \mathrm{MHz}$ & $100 \times 11 \times 13$ & 100 \\
\hline
\end{tabular}


Achieved Results

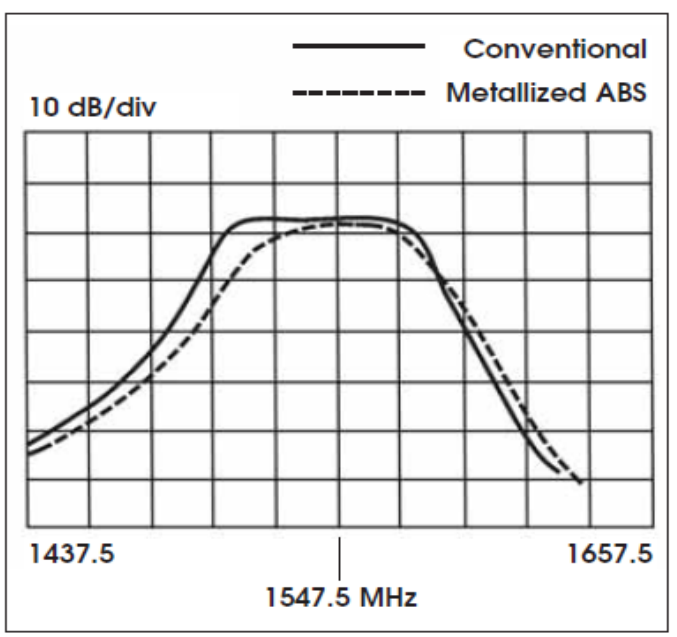

Fig 1: Measurement of the $1537.5 \mathrm{MHz}$ hairpin line filter.

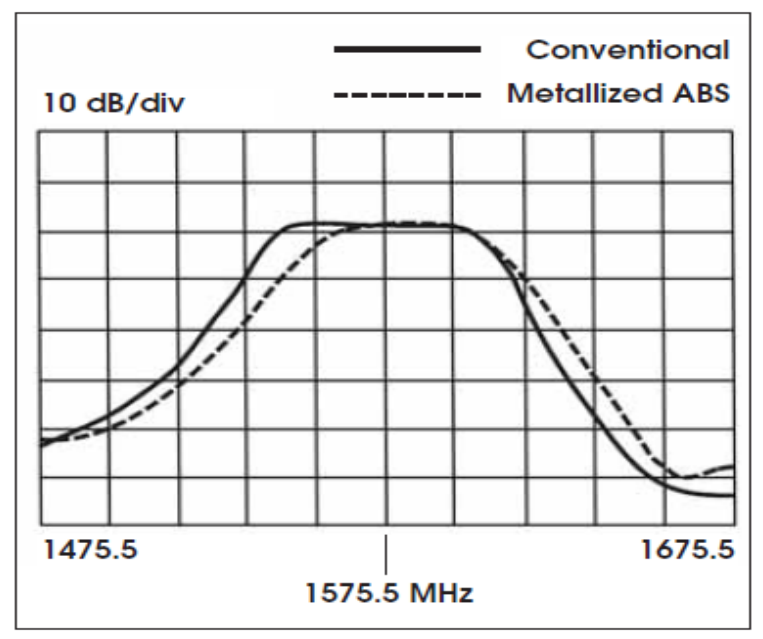

Fig 2: Measurement of the 1575.42 MHz hairpin line filter

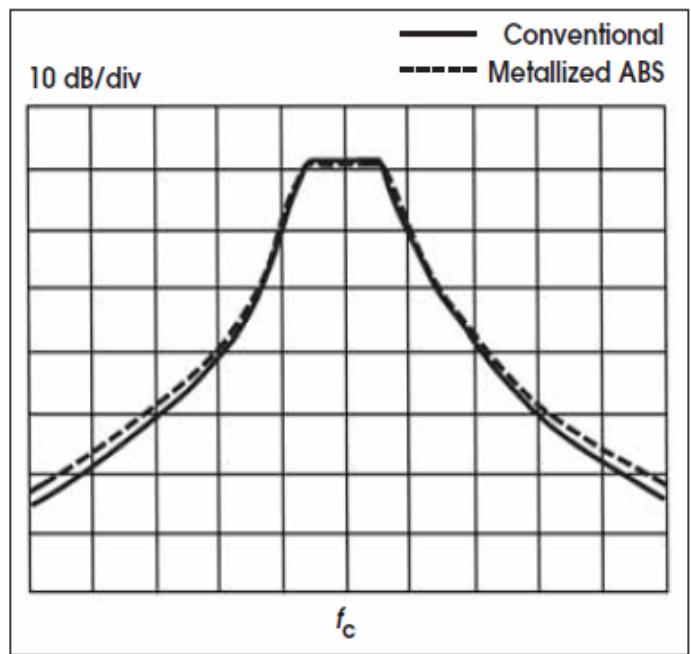

Fig 3: Bandpass plots for the $1537.5 \mathrm{MHz}$ coaxial cavity filter

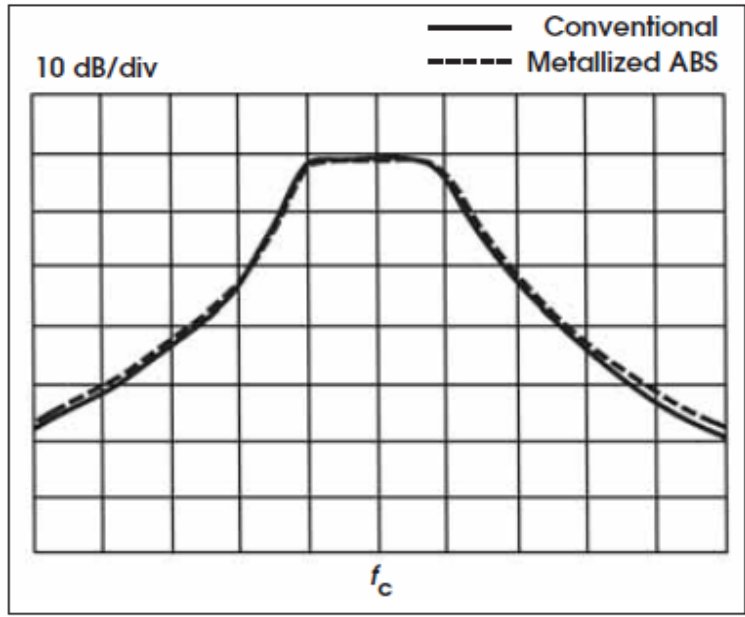

Fig.4: Bandpass plots for the 1636.o MHz coaxial cavity filter

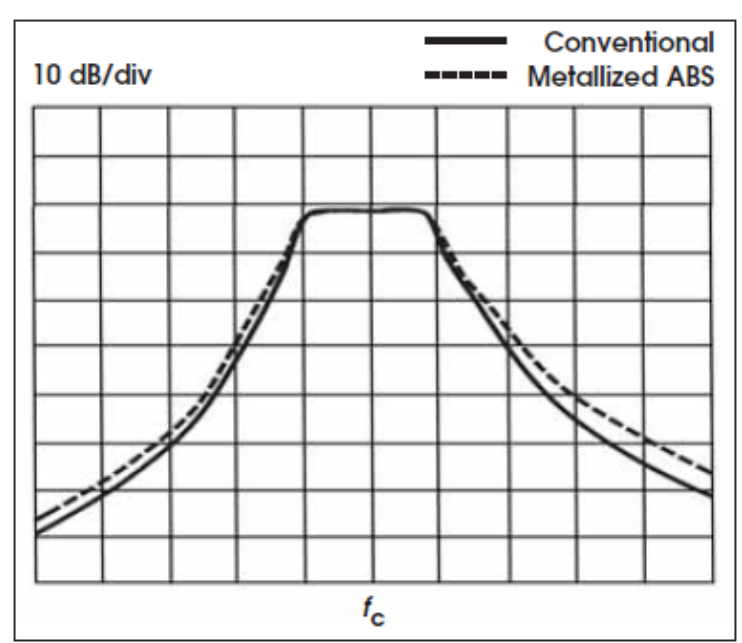

Fig 5: Bandpass plots for the $600 \mathrm{MHz}$ helical filter

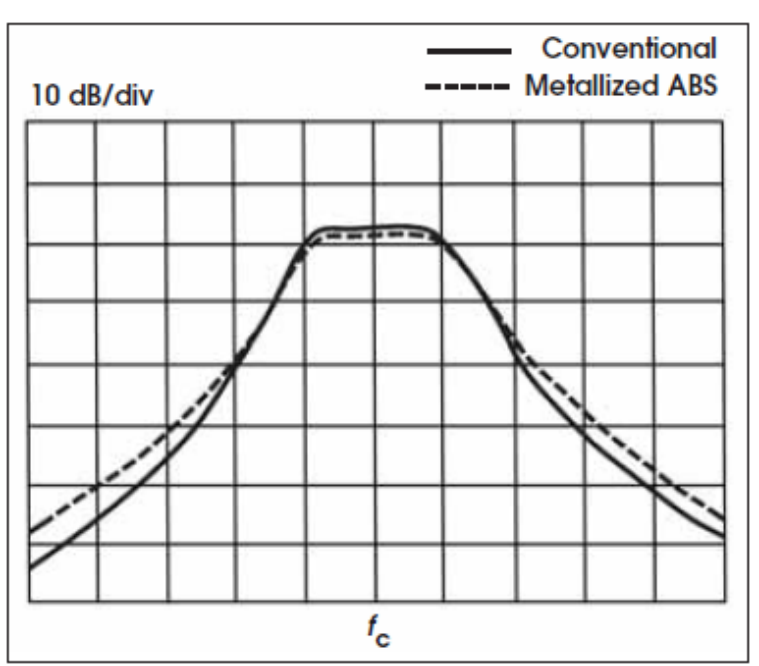

Fig 6: Bandpass plots for the $4190 \mathrm{MHz}$ combline filter 


\section{CONCLUSION}

It can be concluded that metallised ABS plastic at UHF and SHF exhibits electrical behavior similar to that of metals. Although additional work is required before large scale use of ABS can be implemented by industry, the superior performance will undoubtedly make it the material of choice for future high performance microwave equipments in satellite earth stations.

\section{REFERENCES}

[1] Avraam I. Isayev, Advances in ABS Technologies, Wiley Publications, Vol 30, Issue 4, Winter 2011.

[2] D Mitri Kopeliovich, ABS Plastic and Technologies, Materials Engineering Applications and Technologies, 24-03-2011.

[3] Avraam I. Isayev, Advances in ABS Technologies, Wiley Publications, Vol 29, Issue 4, Winter 2010.

[4] Gehm R. Material innovations, AEI, SAE International, Warrendale, PA, December 2009

[5] ABS Plastic Applications, Dynalab Corporation, Rochester, N Y -1461, 2008

[6] Zhu,Y.-Z, Y.J. Xie and Feng "Novel microstrip bandpass filters" Progerss in Electronics Research, PIER, 29-41, 2007

[7] Xiao,J.-K.,S.-W MA,S.Zhang and Y Li, Novel compact band pass filters, Journal of Electromagnetic Waves and Applications,Vol.21, No.10,1341-1351,2007

[8] Deng,P-H., Y. S. Lin, C.H. Wang and C.H. Chen, Compact Microstrip bandpass filters with good stopband rejection, IEEE Transactions on Microwave Theory and Techniques,Vol.54,No.2, 533-539, Feb 2006.

[9] Kazerooni, M. and A Cheldavi,, Simulation, analysis, design and applications of microstrip structure filters using multistrip method Progerss in Electromagnetics Research" PIER, 63, 193-207, 2006

[10] Jen-TasiKuo,Ming-Jyh Maaand Ping-han Lu, Microstrip filter with Compact miniaturized hairpin line resonators" IEEE Microwave Theory and Guided Letters, Vol.10 No.3, March 2005,pp 94-95

[11] D. Pozar, Microwave Engineering , Third Edition, Wiley, 2005. pp. 416-438.

[12] H. Wang and L Zhu Microstrip resonator with ultrabroad rejection bandwidth, Electronic Letter, Vol.40, No.9, pp.1188-1189, Sept.2004

[13] Hong J. S. and Lancaster M. J. Microstrip filters for RF/microwave application, A Wiely-Interscience publications Canada, 2004

[14] Data sheet for ABS plastic AP78EP, ABSOTRON Technical Collaboration with Sumitomo Chemical Engg. Co., Japan, 2002

[15] High performance plated plastics" by Jim Pychwalsk and Martin Bayes, Shipley Co., Newton, MA

[16] Agilent Technologies, Inc. www.agilent.com

[17] Sonnet Software, www.sonnetusa.com

[18] Ansoft-HFSS-3D for Electromagnetic modeling: www.ansoft.com

[19] Zereve A. I. Handbook of filter synthesis, Wiley \& Sons New York. 